\title{
MEKANISME ANTIBIOSIS BACILLUS SUBTILIS B315 UNTUK PENGENDALIAN PENYAKIT LAYU BAKTERI KENTANG
}

\author{
Nur Prihatiningsih ${ }^{1}$, Triwidodo Arwiyanto², Bambang Hadisutrisno² \& Jaka Widada ${ }^{2}$ \\ ${ }^{1}$ Fakultas Pertanian Unsoed Purwokerto Kampus Karangwangkal \\ Jl dr. Suparno Purwokerto 53123 \\ ${ }^{2}$ Fakultas Pertanian UGM Yogyakarta \\ E-mail: prihatiningsihnur@gmail.com
}

\begin{abstract}
Antibiosis mechanism of Bacillus subtilis B315 for controlling potato bacterial wilt disease. Bacillus subtilis B315 isolated from rhizospheric potato has antibiosis mechanism against Ralstonia solanacearum in vitro and become potentially used as controlling method of bacterial wilt in the field. The objectives of this research were to study the mechanism of $B$. subtilis B315 in controlling bacterial wilt disease, to study of B. subtilis B315 potency as both biocontrol and plant growth promoter, and to evaluate the mechanism as biocontrol agent. This green house experiment used CRD (Completely Randomized Design) with 5 treatments and 6 replicates. The treatments were control (without B. subtilis B315), B. subtilis B315 wild type, antibiosis mutant M16, antibiosis mutant M4, and antibiosis mutant M14. Variables observed were incubation period, disease index, infection rate, effectiveness of control, and growth components (i.e number of bud, plant height, leaf area, plant fresh and dry weight). The result of this research showed that $B$. subtilis B315 could delay incubation period, suppressed the disease index up to $64,9 \%$ and could promote the plant growth (leaf area). B. subtilis B315 had the antibiosis and other mechanisms that induced sistemic resistance. The implication of this research was that $B$. subtilis $\mathrm{B} 315$ could be used for biocontrol the bacterial wilt and promoted the potato growth.
\end{abstract}

Key words: antibiosis, Bacillus subtilis B315, bacterial wilt disease control, potato plant growth promote

\begin{abstract}
ABSTRAK
Mekanisme antibiosis Bacillus subtilis b315 untuk pengendalian penyakit layu bakteri kentang. Bacillus subtilis B315 yang diisolasi dari rizosfer kentang mempunyai mekanisme antibiosis terhadap Ralstonia solanacearum secara in vitro. Mekanisme antibiosis secara in vitro ini sebagai potensi B. subtilis B315 untuk mengendalikan penyakit layu bakteri di lahan kentang. Tujuan penelitian adalah untuk mempelajari mekanisme antibiosis $B$. subtilis B315 untuk pengendalian penyakit layu bakteri kentang, dan mempelajari potensi $B$. subtilis B315 sebagai pemicu pertumbuhan tanaman kentang, serta mengevaluasi mekanisme B. subtilis B315 sebagai agensia pengendali hayati. Metode yang digunakan adalah percobaan di rumah kaca dengan Rancangan Acak Lengkap dengan 5 perlakuan dan 6 ulangan. Perlakuannya adalah kontrol (tanpa B. subtilis B315), B. subtilis B315 tipe alami, mutan antibiosis M16, mutan antibiosis M4, mutan antibiosis M14. Variabel yang diamati adalah masa inkubasi, indeks penyakit, laju infeksi, efektivitas pengendalian, komponen pertumbuhan tanaman (jumlah tunas, tinggi tanaman, luas daun, bobot brangkasan segar dan kering). Hasil penelitian menunjukkan bahwa B. subtilis B315 sebagai agensia pengendali hayati penyakit layu bakteri kentang dapat menunda masa inkubasi, menekan indeks penyakit layu bakteri dengan efektivitas $64,9 \%$, menekan laju infeksi dan mampu memicu peningkatan pertumbuhan tanaman yang dilihat dari luas daun. B. subtilis B315 sebagai agensia pengendali hayati mempunyai mekanisme antibiosis dan mekanisme lain yaitu penginduksi ketahanan sistemik. Implikasi hasil penelitian ini adalah B. subtilis B315 dapat digunakan sebagai agensia pengendali hayati dan pemicu peningkatan pertumbuhan tanaman kentang.
\end{abstract}

Kata kunci: antibiosis, Bacillus subtilis B315, pengendalian penyakit layu bakteri, pemicu pertumbuhan tanaman kentang

\section{PENDAHULUAN}

Kentang (Solanum tuberosum L.) di Indonesia merupakan komoditas hortikultura yang mendapat prioritas untuk dikembangkan, dan berpotensi untuk dipasarkan di dalam negeri maupun ekspor. Penyakit layu bakteri yang disebabkan oleh Ralstonia solanacearum ini merupakan kendala dalam budidaya kentang karena dapat menyebabkan kematian tanaman dan merugikan hasil 75\% (Semangun, 1989) dan lebih dari 75\% di Karnataka (Gadewar et al., 1991). Lebih lanjut dijelaskan oleh Ghosh et al. (2009) bahwa hubungan antara kehilangan hasil dan intensitas penyakit adalah linier. Pengendalian penyakit layu bakteri yang 
telah dilakukan adalah dengan cara fitosanitari dan kultur teknis seperti penggunaan umbi bebas penyakit, rotasi tanaman, dan intercropping serta bahan kimia seperti fumigasi dengan methyl bromide, sodium hypochlorite dan bakterisida (Champoiseau et al., 2010; Muthoni et al., 2012).

Penggunaan varietas kentang yang tahan terhadap penyakit layu bakteri dianggap lebih murah dan praktis, karena dengan pestisida kimia sintetik tidak efektif, fitosanitari dan kultur teknis sulit diaplikasikan di lapangan dan agensia pengendali hayati belum tersedia secara komersial (Muthoni et al., 2012). Sebagai alternatif pengendalian yang berwawasan lingkungan adalah dengan menggunakan agensia hayati sebagai biopestisida. Bakteri yang berpotensi sebagai biopestisida dan aman dalam pengelolaan tanaman adalah genus Agrobacterium, Pseudomonas dan Bacillus (Beric et al., 2012). Genus Bacillus mempunyai kemampuan mensintesis beberapa senyawa yang berguna dalam bidang pertanian dan industri. Beberapa metabolit sekunder dihasilkan oleh beberapa spesies dan strain Bacillus yang menunjukkan aktivitas antibakteri dan antijamur terhadap patogen tanaman (Yu et al., 2002; Ongena \& Jacques, 2008).

Bacillus subtilis B315 diperoleh dari rizosfer kentang sehat di antara kentang yang layu di daerah endemik, di Desa Serang Kecamatan Karangreja Kabupaten Purbalingga dengan ketinggian tempat 1200 $\mathrm{m}$ dpl. Pada pengujian sebelumnya secara in vitro, $B$. subtilis B315 mampu menekan pertumbuhan $R$. solanacearum dengan mekanisme antibiosis, menunjukkan zona hambatan sebesar $18 \mathrm{~mm}$ dan dengan mekanisme penghambatan bersifat bakteriostatik. Menurut Junaid et al. (2013), B. subtilis dapat menghasilkan antibiotik sebagai mekanisme antibiosis seperti Bacillomycin D dan iturin yang dihasilkan oleh B. subtilis AU195 dan QST713.

Mekanisme pengendalian hayati menurut Lo (1998) dan Junaid et al. (2013) dapat berupa (1) antibiosis, (2) kompetisi, (3) mikoparasitisme, (4) enzim pendegradasi dinding sel, dan (5) penginduksi ketahanan, (6) pemacu pertumbuhan dan (7) pengoloni rizosfer. Pengendalian secara hayati terhadap patogen tanaman menjadi lebih penting karena tidak menimbulkan residu, aman bagi lingkungan, dan berpengaruh positif pada tanaman. Selain itu, menurut Choudhary \& Johri (2008) agensia hayati seperti Bacillus spp. dapat berperan sebagai pupuk hayati dan agensia pengendali hayati melalui mekanisme antibiosis, sekresi enzim pelisis, dan penginduksi ketahanan sistemik (Induced Systemic Resistance $=$ ISR).
Salah satu mekanisme penekanan oleh strain anggota genus Bacillus adalah antibiosis yang ditunjukkan dengan terbentuknya zona hambatan pada kultur Bacillus spp. yang ditumbuhkan pada medium secara berlapis dengan bakteri patogen. Antibiosis merupakan mekanisme antagonis dengan menghasilkan metabolit sekunder berupa antibiotik atau senyawa mirip antibiotik seperti enzim pelisis, senyawa yang mudah menguap, siderofor, dan substansi toksik lainnya (Haggag $\&$ Mohamed, 2007). Antibiotik secara umum didefinisikan sebagai senyawa organik dengan berat molekul rendah, yang dihasilkan sebagai metabolit sekunder dan menghambat pertumbuhan atau aktivitas metabolisme mikroba lain pada konsentrasi rendah. Krebs et al. (1998) menyatakan bahwa strain Bacillus yang diisolasi dari tanah teridentifikasi sebagai $B$. subtilis mempunyai kemampuan sebagai antibakteri, antijamur, pemacu pertumbuhan tanaman dan penginduksi ketahanan sistemik (Prihatiningsih, 2013). Formulasi $B$. subtilis sebagai pengendali hayati dengan produk "FZB24" telah didaftarkan di Jerman sebagai agensia penguat tanaman.

Mekanisme antibiosis dari suatu agensia hayati dapat dibuktikan dengan cara membuat mutan antibiosis, yaitu mutan yang kehilangan sifat antibiosis namun sifat yang lain masih sama dengan tipe alaminya. Mutasi merupakan perubahan materi genetik yang dapat terjadi karena beberapa faktor seperti mutasi spontan dan mutasi induksi karena mutagen. Mutasi dapat pula diartikan sebagai perubahan sekuen nukleotida dari molekul DNA, biasanya digunakan untuk perubahan pada skala relatif kecil, sedangkan rekombinasi melibatkan perubahan segmen polinukleotida di antara molekul DNA yang berbeda dan dapat menyebabkan penyusunan ulang (Brown, 1989).

Mutan bakteri adalah turunan bakteri tipe alami (tipe liar = wild type), yaitu terjadinya perubahan gen pada bakteri tersebut akibat terjadi mutasi, yang dapat dilihat dari fenotipiknya (Sreeju et al., 2011). Mutan antibiosis B. subtilis RP24 menurut Grover et al. (2009) dikelompokkan menjadi mutan yang tidak menghambat (no antagonism) dan mutan yang menghambat sebagian (partial antagonism). Mikroba dapat mengalami mutasi dengan mutasi spontan atau terinduksi dengan mutagen yang dapat berupa mutagen kimia, fisik seperti sinar UV. Pelczar et al. (2006) menyebutkan bahwa salah satu tipe mutasi adalah terbentuknya mutan yang menunjukkan kemampuan fermentasi yang berubah, meningkat atau menurunnya kemampuan menghasilkan metabolit. 
Permasalahan yang dihadapi adalah apakah pengendalian penyakit layu bakteri dengan $B$. subtilis B315 mengikuti mekanisme antibiosis seperti halnya pengujian antagonisme $B$. subtilis B315 terhadap $R$. solanacearum in vitro atau mempunyai mekanisme lainnya. Tujuan penelitian ini adalah: (1) mempelajari mekanisme antibiosis B. subtilis B315 untuk pengendalian penyakit layu bakteri kentang, (2) mempelajari potensi B. subtilis B315 sebagai pemacu pertumbuhan tanaman, dan (3) mengevaluasi mekanisme B. subtilis $\mathrm{B} 315$ sebagai agensia pengendali hayati. Hipotesis yang diajukan adalah B. subtilis B315 efektif untuk mengendalikan penyakit layu bakteri kentang dengan mekanisme antibiosis, dan mampu memacu pertumbuhan tanaman melalui mekanisme lain yang dimiliki yaitu sebagai penginduksi ketahanan sistemik.

\section{METODE PENELITIAN}

Tempat dan Waktu. Penelitian dilaksanakan di Laboratorium Bakteriologi Fakultas Pertanian UGM dan di kebun percobaan Fakultas Pertanian Unsoed Purwokerto yang terletak di Desa Serang Kecamatan Karangreja Kabupaten Purbalingga pada ketinggian tempat $1200 \mathrm{~m}$ dpl. Penelitian dimulai bulan Februari sampai dengan Juli 2012.

Penyiapan Bahan. Bahan yang digunakan dalam penelitian ini meliputi bakteri antagonis $B$. subtilis $\mathrm{B} 315$, mutan antibiosis B. subtilis B315M16, B. subtilis B315M4 dan B. subtilis B315M14 yang telah dimutasi dengan EMS (Ethyl Methane Sulphonate) pada penelitian sebelumnya. Bakteri patogen $R$. solanacearum $\operatorname{Pr} 7$ yang diisolasi dari tanaman kentang layu di Desa Serang Kecamatan Karangreja Kabupaten Purbalingga. Tanaman kentang yang digunakan dalam penelitian adalah varietas Atlantik, bibit diperoleh dari penangkar benih di Desa Grogol Kecamatan Batur Kabupaten Banjarnegara. Bahan kimia yang digunakan adalah medium biakan YPGA (yeast extract peptone glucose agar) dan YPG cair.
Infestasi $R$. solanacearum dan $B$. subtilis B315. $R$. solanacearum diinfestasikan ke dalam tanah dengan cara disemprotkan dalam tanah sambil diaduk agar $R$. solanacearum merata dilakukan 2 hari sebelum tanam. Kepadatan populasi $R$. solanacearum yang diaplikasikan adalah $10^{8} \mathrm{cfu} / \mathrm{ml}$. Aplikasi B. subtilis B315 dan mutan antibiosis dilakukan dengan cara perendaman umbi bibit kentang 30 menit sebelum tanam dengan kerapatan populasi $10^{8} \mathrm{cfu} / \mathrm{ml}$ pada masingmasing perlakuan. Perlakuan yang diujikan pada tanaman kentang di rumah kaca dapat dilihat pada Tabel 1.

Perlakuan B. subtilis B315 adalah dengan cara perendaman benih (umbi bibit) ke dalam suspensi $B$. subtilis B315 dengan kerapatan $10^{8}$ cfu/ml dan dosis $1000 \mathrm{ml}$ suspensi untuk 8 umbi. Setiap perlakuan terdiri atas empat tanaman dan diulang enam kali, dirancang secara Acak Kelompok Lengkap. Variabel yang diamati: masa inkubasi, indeks penyakit, laju perkembangan penyakit (infection rate $=\mathrm{r}$ ), populasi jamur total, dan $R$. solanacearum.

Komponen pertumbuhan tanaman antara lain jumlah daun, luas daun, tinggi tanaman, bobot segar dan kering brangkasan, dan komponen hasil tanaman meliputi, jumlah umbi, bobot per umbi, dan bobot umbi per tanaman. Data pendukung adalah suhu dan kelembaban udara, serta suhu dan kelembapan tanah, pH tanah, DHL (daya hantar listrik), kandungan C organik, $\mathrm{N}$ total, dan $\mathrm{P}$ tersedia, $\mathrm{K}$ tersedia serta ketahanan agregat.

Perhitungan Indeks Penyakit layu bakteri berdasarkan rumus sebagai berikut:

$$
\mathrm{IP}=\frac{\sum_{i=1}^{k}(\mathrm{k} \times \mathrm{nk})}{\mathrm{Z} \times \mathrm{N}} 100 \%
$$

dengan:

IP = indeks penyakit

$\mathrm{n}=$ jumlah tanaman pada kategori $\mathrm{k}$

$\mathrm{k}=$ kategori penyakit

$\mathrm{N}=$ jumlah tanaman yang diamati

$\mathrm{Z}=$ nilai kategori penyakit tertinggi

Tabel 1. Susunan perlakuan

\begin{tabular}{ccl}
\hline No & Simbol & \multicolumn{1}{c}{ Perlakuan } \\
\hline 1 & K & tanpa B. subtilis B315 \\
2 & B1 & B. subtilis B315 tipe alami \\
3 & B2 & mutan antibiosis M16 \\
4 & B3 & mutan antibiosis M4 \\
5 & B4 & mutan antibiosis M14 \\
\hline
\end{tabular}


Skala penilaian kerusakan (kategori) menurut Arwiyanto \& Hartana (2001):

$0=$ tidak ada gejala

$1=1-10 \%$ daun layu

$2=11-30 \%$ daun layu

$3=$ lebih dari $30 \%$ daun layu

Perhitungan laju infeksi berdasarkan rumus yang dikemukakan oleh van der Plank (1963) sebagai berikut:

dengan:

$$
X t=X o \cdot e^{r t}
$$

$\mathrm{Xt}=$ proporsi penyakit pada waktu $\mathrm{t}$

$\mathrm{Xo}=$ proporsi penyakit pada awal pengamatan

$\mathrm{e}=$ konstanta logaritma $(2,718)$

$\mathrm{r}=$ laju infeksi/laju perkembangan penyakit (unit/hari)

$\mathrm{t}=$ waktu

Nilai r dihitung berdasarkan kriteria penyakit layu bakteri termasuk simple interest disease (SID), maka:

$$
\mathrm{r}=\frac{2,3}{\mathrm{t}}\left(\log \frac{1}{1-\mathrm{X}_{\mathrm{t}}}-\log \frac{1}{\mathrm{X}_{\mathrm{O}}}\right)
$$

Data karakterisasi Bacillus spp. dan uji antagonistik dianalisis secara deskriptif, sedangkan data penelitian di rumah kaca dianalisis dengan sidik ragam dan apabila berbeda nyata dilanjutkan dengan DMRT (Duncan Multiple Range Test) dengan taraf kesalahan $5 \%$.

\section{HASIL DAN PEMBAHASAN}

Perlakuan B. subtilis B315 tipe alami dan mutan antibiosisnya mempengaruhi masa inkubasi, indeks penyakit dan laju infeksi (Tabel 2). Perlakuan B. subtilis B315 tipe alami mampu menunda masa inkubasi sampai dengan 7 hari. Perlakuan B. subtilis B315 tipe alami menunjukkan masa inkubasi $36 \mathrm{hst}$, sedangkan rata-rata pada kontrol menunjukkan masa inkubasi selama 29,2 hari (Tabel 2), meskipun pada umur 26 hst tanaman yang diberi perlakuan kontrol dan mutan antibiosis M16 sudah menunjukkan gejala layu.

Berdasarkan hasil analisis statistik indeks penyakit layu bakteri, pengaruh pada perlakuan B. subtilis B315 tipe alami dan mutan antibiosis M16 berbeda nyata. Namun demikian dibandingkan dengan 2 mutan antibiosis yang lain (M4 dan M14) perlakuan B. subtilis B315 tipe alami tidak berbeda nyata. B. subtilis B315 tipe alami mampu menekan penyakit layu bakteri dengan efektivitas penekanan 64,9\%, sedangkan mutan M16 hanya mampu menekan $49,9 \%$. Efektivitas penekanan terhadap penyakit layu bakteri pada mutan antibiosis M14 sama dengan B. subtilis B315 tipe alami.

Kemampuan mutan antibiosis dalam penekanan penyakit layu bakteri menunjukkan bahwa $B$. subtilis B315 mempunyai mekanisme lain dalam pengendalian hayati terhadap penyakit layu bakteri. Mekanisme lain dari agensia pengendali hayati adalah secara tidak langsung sebagai pemacu pertumbuhan tanaman dan menginduksi ketahanan sistemik. Lo (1998) menyatakan bahwa mekanisme pengendalian hayati meliputi 1) antibiosis, 2) kompetisi, 3) mikoparasitisme, 4) enzim pendegradasi dinding sel, dan 5) ketahanan terimbas atau terinduksi.

Peran B. subtilis B315 sebagai penginduksi ketahanan sistemik dapat dilihat dari berkurangnya penyakit lain pada tanaman kentang seperti hawar daun oleh Phytophthora infestans dengan intensitas penyakit kurang dari $10 \%$. Hasil penelitian di rumah kaca ini konsisten dengan hasil penelitian secara in vitro pada penelitian sebelumnya bahwa mutan antibiosis M14 mampu menghambat $R$. solanacearum dan di rumah kaca mampu menekan indeks penyakit dengan efektivitas 64,9\%. Mutan antibiosis M16 kehilangan kemampuan menghambat $R$. solanacearum in vitro, dan di rumah kaca mampu menghambat indeks penyakit layu bakteri sebesar $49,9 \%$. Hal inilah yang menunjukkan bahwa $B$. subtilis B315 mempunyai mekanisme lain dalam menekan penyakit layu bakteri.

Perkembangan penyakit layu bakteri pada kentang dengan perlakuan $B$. subtilis B315 tipe alami dan mutan antibiosis menunjukkan kurva monomolekular (Gambar 1), yaitu perkembangan penyakit tipe bunga sederhana (simple interest disease $=S I D$ ), karena $R$. solanacearum adalah patogen tular tanah. ContrerasMedina et al. (2009) mengemukakan bahwa perkembangan penyakit dengan model monomolekular terjadi pada penyakit dengan patogen berdaur tunggal selama musim tanam (SID). Patogen yang mengikuti daur tunggal selama musim tanam adalah patogen tular tanah termasuk bakteri $R$. solanacearum. Penekanan indeks penyakit layu bakteri pada kentang dengan perlakuan B. subtilis B315 dengan cara perendaman benih, menunjukkan efektivitas penekanan sebesar 64,9\%. Gejala penyakit layu bakteri di rumah kaca dengan aplikasi $B$. subtilis B315 ditunjukkan dalam Gambar 2.

Bakterisasi biji diikuti dengan perendaman akar dengan bakteri antagonis di rumah kaca sangat efektif mengendalikan penyakit layu bakteri. Hasil penelitian di lapangan pada tanah yang terinfestasi $R$. solanacearum secara alami, dengan perlakuan bakteri antagonis mampu 
Tabel 2. Masa inkubasi, indeks penyakit dan laju infeksi penyakit layu bakteri kentang setelah aplikasi $B$. subtilis $\mathrm{B} 315$

\begin{tabular}{ccccc}
\hline Perlakuan & $\begin{array}{c}\text { Masa inkubasi } \\
(\mathrm{hst})\end{array}$ & $\begin{array}{c}\text { Indeks penyakit } \\
(\%)\end{array}$ & $\begin{array}{c}\text { Laju infeksi (r) } \\
\text { (unit/hari) }\end{array}$ & $\begin{array}{c}\text { Efektivitas } \\
\text { penekanan (\%) }\end{array}$ \\
\hline K & $29,2 \mathrm{~b}$ & $83,3 \mathrm{a}$ & 0,0459 & - \\
B 1 & $36,0 \mathrm{a}$ & $29,2 \mathrm{c}$ & 0,0098 & 64,9 \\
B 2 & $35,7 \mathrm{a}$ & $41,7 \mathrm{~b}$ & 0,0146 & 49,9 \\
B3 & $35,4 \mathrm{a}$ & $34,7 \mathrm{bc}$ & 0,0180 & 58,3 \\
B 4 & $36,3 \mathrm{a}$ & $29,2 \mathrm{c}$ & 0,0098 & 64,9 \\
\hline
\end{tabular}

Angka yang diikuti oleh huruf yang sama pada kolom yang sama menunjukkan tidak berbeda nyata pada uji Duncan taraf kesalahan 5\%. hst: hari setelah tanam, K: tanpa B. subtilis B315; B1: B. subtilis B315 tipe alami; B2: mutan antibiosis M16; B3: mutan antibiosis M4; B4: mutan antibiosis M14.

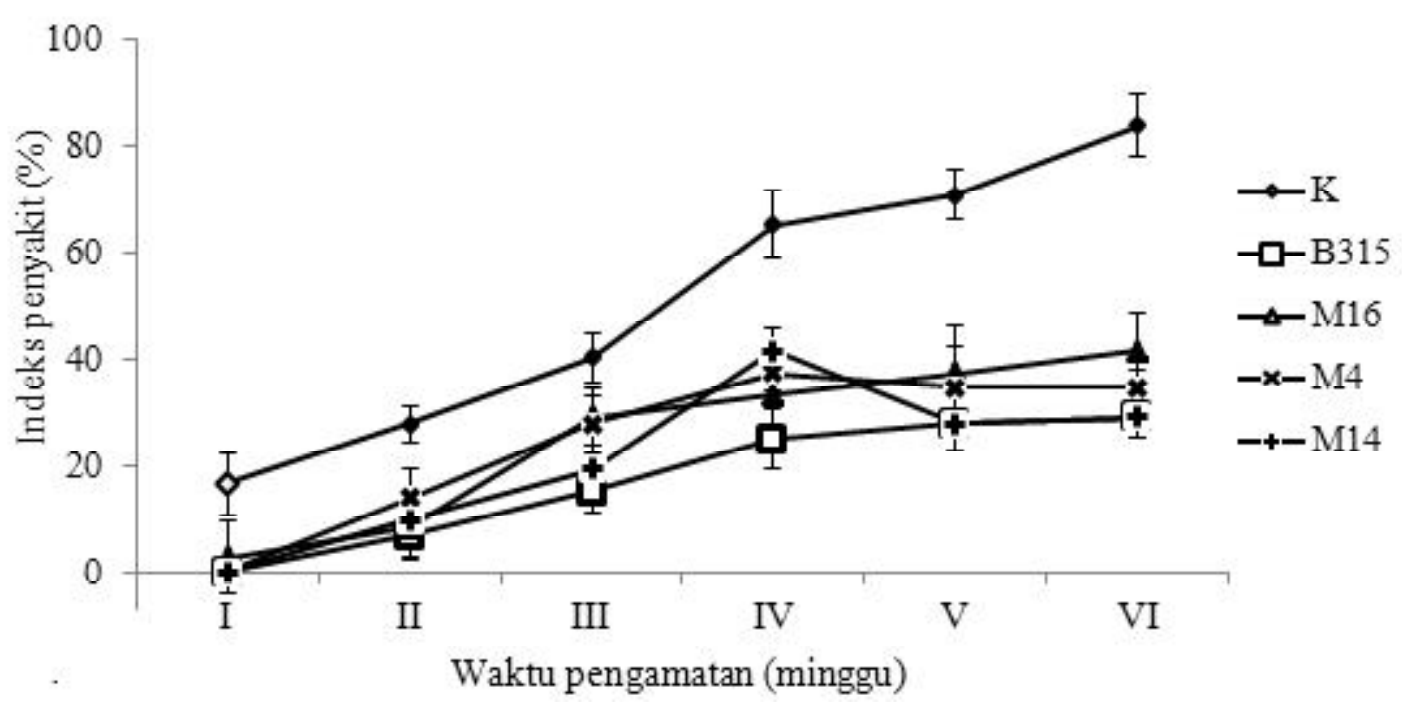

Gambar 1. Perkembangan penyakit layu bakteri setelah perlakuan Bacillus sp. B315 tipe alami dan mutan antibiosis
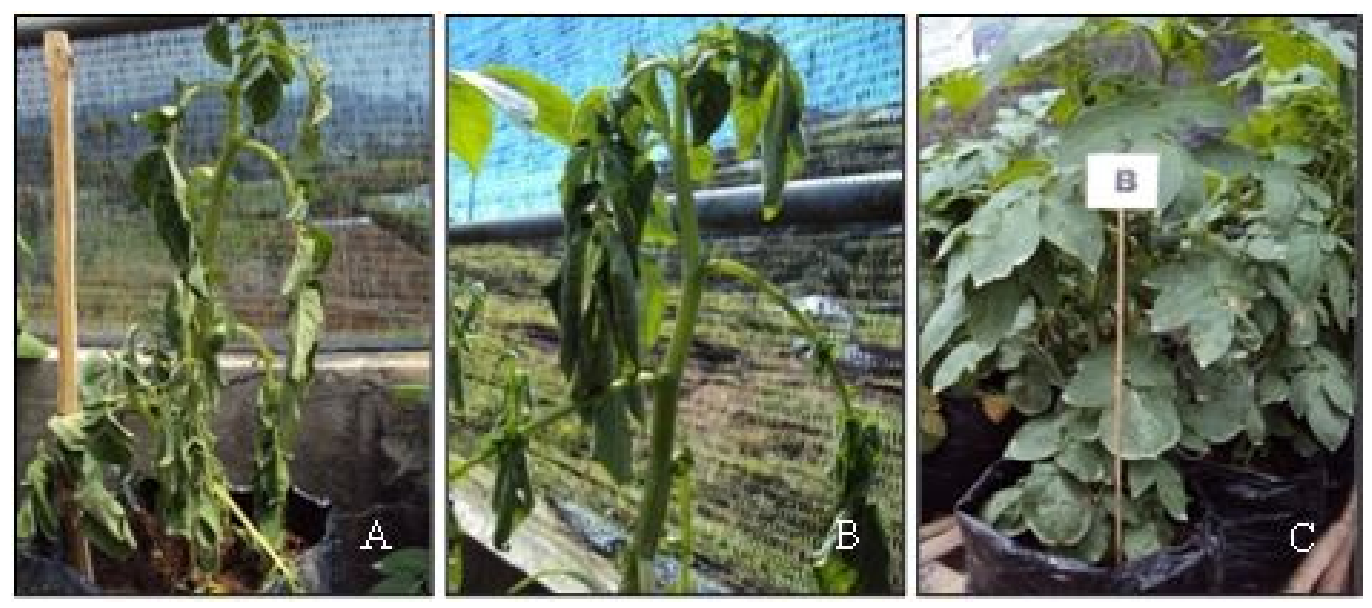

Gambar 2. Gejala layu bakteri pada kontrol (A), perlakuan mutan Bacillus sp. B315M16 (B) dan tanaman sehat pada perlakuan Bacillus sp. B315 tipe alami 
menekan intensitas layu bakteri sampai 40\% (Yulianti et al., 1999). Karuna et al. (2003) menyatakan bahwa bakterisasi antagonis dengan $B$. subtilis pada biji tomat sangat efektif untuk mengendalikan penyakit layu bakteri oleh $R$. solanacearum.

Berdasarkan hasil pengamatan komponen pertumbuhan dan hasil kentang setelah perlakuan B. subtilis $\mathrm{B} 315$ tipe alami dan mutan antibiosis menunjukkan bahwa pada komponen pertumbuhan, hanya jumlah tunas dan luas daun yang berbeda nyata (Tabel 3). Perlakuan mutan M16 tidak berbeda nyata dengan perlakuan B. subtilis B315 tipe alami dan kontrol pada jumlah tunas, dan juga tidak berbeda nyata dengan perlakuan mutan M4 dan M14, namun B. subtilis B315 tipe alami dan kontrol berbeda nyata dengan mutan M4 dan M14.

Perlakuan mutan M14 menunjukkan hasil terbaik dalam meningkatkan luas daun yaitu $287,56 \mathrm{~cm}^{2}$, sedangkan pada kontrol (tanpa Bacillus) luas daun hanya $182,25 \mathrm{~cm}^{2}$. Luas daun pada perlakuan $B$. subtilis B315 tipe alami sebesar $205,11 \mathrm{~cm}^{2}$ yang berbeda nyata dengan perlakuan lainnya, yaitu M16 sebesar 232,58 cm². Padahal mutan M14 adalah kelompok mutan III yang masih mampu menghambat $R$. solanacearum in vitro meskipun zona hambatannya kecil $(3,3 \mathrm{~mm})$ atau penghambatannya hanya mencapai $36,26 \%$ (Prihatiningsih, 2013). Dengan kata lain mutan ini kehilangan sedikit sifat antibiosisnya, namun sifat yang lain misalnya dalam meningkatkan komponen pertumbuhan seperti luas daun tidak hilang atau masih sama dengan tipe alaminya. Hal ini dapat dikatakan bahwa $B$. subtilis B315 mempunyai mekanisme lain dalam mengendalikan penyakit layu bakteri kentang, yaitu dengan memacu pertumbuhan tanaman.
Meskipun efektivitas pengendalian penyakit layu bakteri pada perlakuan $B$. subtilis B315 tipe alami sebesar 64,9\%, dan mutan M16 efektif sebesar 49,9\%, namun pengaruhnya terhadap komponen pertumbuhan tanaman adalah positif dapat meningkatkan luas daun. Sitompul \& Guritno (1995) berpendapat bahwa luas daun merupakan parameter utama dalam pertumbuhan tanaman karena daun secara umum dipandang sebagai organ produsen fotosintat utama. Oleh karena itu pengamatan luas daun sebagai indikator pertumbuhan dan sebagai penunjang untuk menjelaskan proses pertumbuhan tanaman yang terjadi seperti pada pembentukan biomassa tanaman. Peningkatan pertumbuhan tanaman ditunjukkan oleh peningkatan luas daun setelah aplikasi $B$. subtilis B315, sehingga dapat menyekap cahaya matahari yang lebih banyak, namun juga disertai peningkatan kemampuan fotosintesis per luas daun yang ditunjukkan oleh nisbah bobot kering brangkasan/luas daun yang lebih tinggi yaitu 0,1828 (Tabel 3). Komponen pertumbuhan yang lain yaitu tinggi tanaman, bobot segar dan bobot kering brangkasan tidak berbeda nyata pada semua perlakuan. Hasil ini menunjukkan bahwa dengan perlakuan $B$. subtilis B315 baik tipe alami maupun mutan antibiosisnya tidak memengaruhi tinggi tanaman, bobot segar dan bobot kering brangkasan.

Berdasarkan hasil pengamatan populasi jamur total dan populasi $R$. solanacearum setelah perlakuan B. subtilis B315 tipe alami dan mutan antibiosis, menunjukkan bahwa populasi jamur total pada kerapatan $10^{3} \mathrm{cfu} / \mathrm{g}$ tanah. dan populasi $R$. solanacearum dengan kerapatan $10^{4} \mathrm{cfu} / \mathrm{g}$ tanah (Tabel 4 ). Jamur yang tumbuh dari hasil isolasi rizosfer dengan perlakuan $B$. subtilis B315, berupa koloni yang berwarna putih, putih dengan

Tabel 3. Komponen pertumbuhan kentang setelah aplikasi B. subtilis B315

\begin{tabular}{lccccccc}
\hline Perlakuan & $\begin{array}{c}\text { Jumlah } \\
\text { tunas }\end{array}$ & $\begin{array}{c}\text { Tinggi } \\
\text { tanaman } \\
(\mathrm{cm})\end{array}$ & $\begin{array}{c}\text { Jumlah } \\
\text { daun }\end{array}$ & $\begin{array}{c}\text { Luas daun } \\
\left(\mathrm{cm}^{2}\right)\end{array}$ & $\begin{array}{c}\text { Bobot segar } \\
\text { brangkasan } \\
(\mathrm{g})\end{array}$ & $\begin{array}{c}\text { Bobot kering } \\
\text { brangkasan } \\
(\mathrm{g})\end{array}$ & $\begin{array}{c}\text { Nisbah } \\
\mathrm{BKB} / \\
\mathrm{LD}\end{array}$ \\
\hline $\mathrm{K}$ & $5,06 \mathrm{a}$ & $42,63 \mathrm{a}$ & $26,05 \mathrm{a}$ & $182,25 \mathrm{~d}$ & $104,17 \mathrm{a}$ & $24,58 \mathrm{a}$ & 0,1349 \\
B315 & $5,09 \mathrm{a}$ & $47,92 \mathrm{a}$ & $30,17 \mathrm{a}$ & $205,11 \mathrm{c}$ & $135,00 \mathrm{a}$ & $37,50 \mathrm{a}$ & 0,1828 \\
B315M16 & $4,85 \mathrm{ab}$ & $47,65 \mathrm{a}$ & $26,12 \mathrm{a}$ & $232,58 \mathrm{~b}$ & $132,92 \mathrm{a}$ & $35,42 \mathrm{a}$ & 0,1523 \\
B315M4 & $3,71 \mathrm{~b}$ & $51,17 \mathrm{a}$ & $26,50 \mathrm{a}$ & $225,60 \mathrm{~b}$ & $135,83 \mathrm{a}$ & $32,92 \mathrm{a}$ & 0,1459 \\
B315M14 & $3,71 \mathrm{~b}$ & $42,52 \mathrm{a}$ & $24,84 \mathrm{a}$ & $287,56 \mathrm{a}$ & $120,83 \mathrm{a}$ & $27,92 \mathrm{a}$ & 0,0970 \\
\hline
\end{tabular}

Angka yang diikuti oleh huruf yang sama pada kolom yang sama menunjukkan tidak berbeda nyata pada uji Duncan taraf kesalahan 5\%. K: tanpa B. subtilis B315; B: B. subtilis B315 tipe alami; B315M16: mutan antibiosis B. subtilis B315 (M16); B315M4: mutan antibiosis B. subtilis B315 (M4); B315M14: mutan antibiosis B. subtilis B315 (M14). BKB: Bobot kering brangkasan, LD: luas daun. 
Tabel 4. Populasi jamur total dan R. solanacearum setelah perlakuan B. subtilis B315

\begin{tabular}{ccc}
\hline Perlakuan & $\begin{array}{c}\text { Populasi jamur total } \\
\left(10^{3} c f u / g \text { tanah dalam PD A+strep }\right)\end{array}$ & $\begin{array}{c}\text { Populasi } R \text {. solanacearum } \\
\left(10^{4} \text { cfu/g tanah dalam (CPG-TTC) }\right.\end{array}$ \\
\hline K & 10,10 & 90,90 \\
B 1 & 4,00 & 15,00 \\
B 2 & 15,50 & 17,00 \\
B 3 & 4,20 & 50,00 \\
B 4 & 10,05 & 30,20 \\
\hline
\end{tabular}

tengah abu-abu dan putih kekuningan. Berdasarkan pada warna koloni jamur yang tumbuh teridentifikasi sebagai jamur yang termasuk kelompok Fusarium sp., Phytophthora sp., Pythium sp., Trichoderma sp., Aspergillus sp., dan Penicillium sp. Jamur-jamur tersebut dapat berupa patogen tanaman kentang yang pada daur hidupnya bertahan di dalam tanah, dan juga dapat merupakan jamur kelompok saprofit maupun antagonis. Barea et al. (2005) mengemukakan bahwa jamur yang terdapat di rizosfer yaitu Fusarium sp., Rhizoctonia sp., Phytophthora sp., Pythium sp., Trichoderma sp., yang berasosiasi dengan mikroba lain baik sebagai patogen, saprofit maupun antagonis. Jamurjamur tersebut berkompetisi dalam kolonisasi, situs infeksi, dan kompetisi dalam memperoleh sumber karbon sebagai nutrien dan kompetisi dalam signal untuk mengkhelat besi.

Populasi $R$. solanacearum setelah akhir penelitian menunjukkan terjadi penurunan dibandingkan dengan populasi pada waktu infestasi ke dalam tanah, yaitu 23,3 x $10^{8}$ cfu/ml menjadi kerapatan $10^{4}$ cfu/g tanah. Kerapatan populasi B. subtilis B315 lebih tinggi dibandingkan dengan kerapatan populasi $R$. solanacearum yaitu $10^{6} \mathrm{cfu} / \mathrm{g}$ tanah kering oven, meskipun mengalami penurunan dibandingkan dengan pada saat perlakuan untuk perendaman benih yaitu 4,1 x $10^{8}$ cfu/ml.

Hal ini menunjukkan bahwa perkembangan $B$. subtilis B315 di dalam tanah lebih banyak dan mampu bertahan sampai dengan akhir penelitian dibandingkan dengan patogen $R$. solanacearum. B subtilis B315 juga mampu mengendalikan penyakit hawar daun oleh jamur Phytophthora infestans dengan intensitas penyakit hawar daun kurang dari $10 \%$.

\section{SIMPULAN}

B. subtilis $\mathrm{B} 315$ mampu menunda masa inkubasi 7 hari dan mengendalikan penyakit layu bakteri dengan efektivitas sebesar $64,9 \%$. B. subtilis B315 juga mampu meningkatkan pertumbuhan tanaman pada luas daun. Mekanisme pengendalian penyakit layu bakteri kentang oleh B. subtilis B315 adalah antibiosis dan penginduksi ketahanan sistemik, yang ditunjukkan dengan peningkatan pertumbuhan tanaman dan penekanan penyakit hawar daun oleh jamur $P$. infestans serta penekanan populasi jamur total.

\section{SANWACANA}

Ucapan terima kasih disampaikan kepada Direktorat Jenderal Pendidikan Tinggi atas dana yang diberikan melalui Beasiswa Program Pasca Sarjana (BPPS) selama mengikuti tugas belajar S3 di Fakultas Pertanian UGM, dari tahun 2009 s/d 2013.

\section{DAFTAR PUSTAKA}

Arwiyanto T \& Hartana I. 2001. Percobaan lapangan pengendalian hayati penyakit layu bakteri tembakau (Ralstonia solanacearum). Mediagama 3: 7-14.

Barea JM, Pozo MJ, Azcon R, \& Azcon-Agullar C. 2005. Microbial co-operation in the rhizosphere. J. Exp. Bot. 56(417): 1761-1778.

Beric T, Kojic M, Stankovic S, Topisirovic L, Degrassi G, Myers M, Venturi V, \& Fira D. 2012. Antimicrobial activity of Bacillus sp. natural isolates and their potential use in the biocontrol of phytopathogenic bacteria. Food Technol. Biotechnol. 50(1): 25-31.

Brown TA. 1989. Genetics: a Molecular Approach. Van Nostrand Reinhold (International) Co.Ltd, London.

Champoiseau PG, Jones JB, Momol TM, Pingsheng J, Allen C, Norman DJ, \& Caldwell K. 2010. Ralstonia solanacearum Race 3 biovar 2 causing brown rot of potato, bacterial wilt of tomato and southern wilt of geranium. http:// 
plantpath.ifas.ufl.edu/rsol/NRI_Project/ Projectsummary.html. Diunduh 12 November 2012.

Choudhary DK \& Johri BN. 2008. Interaction of Bacillus spp. and plants-with special reference to induced systemic resistance (ISR). <http:// www.sciencedirect.com/science?>. Diunduh 28 Februari 2009.

Contreras-Medina LM, Torres-Pacheco I, GuevaraGonzalez RG, Romero-Troncoso RJ, TerolVillalobos IR, \& Osornio-Rios RA. 2009. Mathematical modeling tendencies in plant pathology. Afr. J. Biotechnol. 8 (25): 73997408.

Gadewar AV, Travedi TP, \& Shekawat. 1991. Potato in Karnataka. Technical Bulletin 17: 33.

Ghosh PP, Mandal D, Laha S, \& Dasgupta MK. 2009. Dynamics and severity model in managing fungal diseases. J. Plant Prot. Sci. 1(1): 55-59.

Grover M, Nain L, \& Saxena AK. 2009. Comparison between Bacillus subtilis RP24 and its antibioticdefective mutants. World. J. Microbiol. Biot. 25(8): 1329-1335.

Haggag WM \& Mohamed HAA. 2007. Biotechnological aspects of microorganism used in plant biological control. World J. Agric. Sci. 3(6): 771-776.

Junaid JM, Dar NA, Bhat TA, Bhat AH, \& Bhat MA. 2013. Commercial biocontrol agents and their mechanism of action in the management of plant pathogens. Int. J. Modern Plant \& Anim. Sci. 1(2): 39-57.

Karuna K, Khan ANA, \& Ravikumar MR. 2003. Potential of biocontrol agents in the management of bacterial wilt of tomato caused by Ralstonia solanacearum International Bacterial Wilt Symposium. <http://www.inra.fr/internet/ departement/PATHOV/2 ${ }^{\text {nd }}$-IBWS/B3.html>. Diunduh 9 Mei 2003.

Krebs B, Hoding B, Kubart S, Workie MA, Junge H, Schmiedeknecht G, Grosch R, Bochow H, \& Hevest M. 1998. Use of Bacillus subtilis as biocontrol agent. 1. Activities and characterization of Bacillus subtilis strains. $J$. Plant Dis.Prot. 105(2): 181-197.
Lo CT. 1998. General mechanisms of action of microbial biocontrol agents. Plant Pathol. Bull. 7: 155166.

Muthoni J, Shimelis H, \& Melis R. 2012. Management of bacterial wilt (Ralstonia solanacearum Yabuuchi et al.,1995) of potatoes: opportunityfor host resistance in Kenya. J. Agric. Sci. 4(9): 64-78.

Ongena M \& Jacques P. 2008. Bacillus lipopeptides: versatile weapons for plant disease biocontrol. Trends Microbiol. 16(3): 115-125.

Pelczar, Michael J, \& Chan ECS. 2006. Dasar-Dasar Mikrobiologi. Universitas Indonesia Press. Jakarta.

Prihatiningsih N. 2013. Aktivitas Antibiosis Bacillus sp. B315 sebagai agensia pengendali hayati Ralstonia solanacearum pada Kentang. Disertasi. Program Pasca Sarjana Fakultas Pertanian Universitas Gadjah Mada. Yogyakarta.

Semangun H. 1989. Penyakit-Penyakit Tanaman Hortikultura di Indonesia. Gadjah Mada University Press. Yogyakarta.

Sitompul SM \& Guritno B. 1995. Analisis Pertumbuhan Tanaman. Gadjah Mada University Press. Yogyakarta.

Sreeju SN, Babu MM, Mariappan C, \& Selvamohan T. 2011. Effect of physical and chemical mutagens on biopolmer producing strains and RAPD analysis of mutated strains. Arch. Appl. Sci. Res. 3(6): 233-246.

Van der Plank JE. 1963. Plant Disease: Epidemics and Control. Academic Press, New York.

Yu GY, Sinclair JB, Hartman GL, \& Bertagnolli BL. 2002. Production of Iturin A by Bacillus smyloliquefaciens suppressing Rhizoctonia solani. Soil Biol. Biochem. 34: 955.

Yulianti T, Ibrahim N, \& Dalmadiyo G. 1999. Pemanfaatan mikrobia antagonis untuk mengendalikan penyakit lincat. Prosiding Kongres Nasional XV dan Seminar Ilmiah PFI I. pp. 632-650. 